SB 413

.D13 B6

Copy 1

The Harvesting and Storage of Dahlias

A Bolles Dahlia Booklet 
s. 


\section{The Harvesting and Storage of Dahlias}

by

\section{CHARLTON BURGESS BOLLES}

Media, Pennsylvania

Member The American Dahlia Society

and The California Dahlia Society

Copyright, 1921, By Charlton Burgess Bolles

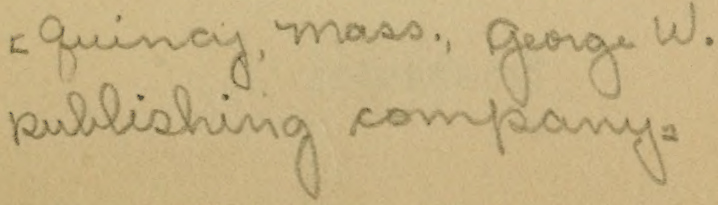




\section{$S B 413$
$D / 3 B 6$}

A List of the

Bolles Dahlia Booklets

1 HISTORY OF THE DAHLIA

2 WHY GROW DAHLIAS?

3 PROPAGATION OF THE DAHLIA

4 CULTIVATION OF THE DAHLIA

5 DAHLIA GROWING COMMERCIALLY

6 FERTILIZERS AND LARGE BLOOMS

7 THE ENEMIES AND PESTS OF DAHLIAS

8 THE HARVESTING AND STORAGE OF DAHLIAS

Price Twenty-five Cents

Address orders to

CHARLTON B. BOLLES

Media, Penn.

$D E C-21921$

()) C.A 530541 


\section{The Harvesting and Storage of Dahlias}

IGGING and storage of dahlias end the joyous cycle of the most brilliant and gorgeous flower of the temperate zone. Planted with great expectations, tended and cultivated with "miser care," the wonderful blooms keenly delighted in as they revealed their amazing glories of form and color and profusion, their decline into the sere and yellow leaf of old age watched with a regretful eye, there comes a night, at last, sometimes as late as November 20, even as far north as New York or Philadelphia, when Jack Frost waves his baton for the finale, and stops the performance of this wonderful orchestra of color and beauty for the season.

As much thought and care, and even imagination must now be put into the harvesting and storage of the roots as has been lavished upon their cultivation and enjoyment. Wrapped up in the earth-colored tubers are the glories of another summer. The dahlia grower must visualize the planting of the far-away next spring, the summer blooms he hopes to enjoy again, and the next harvest, a year away. If he will go over in his mind the successive stages of the season's work now ending, and the duplication of this work, with improvements, for the year to come, the grower will dig and store his precious tubers more carefully, 
and will anticipate and prevent not a few annoyances and even serious troubles. He can lessen his tribulations and enlarge his joys by doing certain careful things at harvest time.

Like most root crops dahlias must not be dug until they have fully matured, if climate and weather allow. The most desirable method is to wait until frost has killed the foliage, and then delay digging five to seven days, for it is believed that the sap in the killed plants flows down and is transformed into plant food in the tubers against the time of sprouting in the spring, and that tubers so reenforced make a better start when planted.

But the amateur, blessed with academic or theoretical temper of mind faces considerable danger of loss, if he is located in some sections, where the frost is long delayed in the autumn. Having obtained so much help from books and by following the ideals of the best gardeners, he will wait for frost duly to arrive and do its work. If this frost comes late, say around or after November first in many regions, it will come with a vengeance when it does visit the dahlia plantation, and there is decided danger that freezing will be deep enough to injure the crowns of the tubers, wherein are located the so necessary "eyes" or buds for next year's plants. One amateur with several hundred dollars worth of fine varieties was a great believer in theory, and had followed theory with many profitable 
results for years. This particular year, in the vicinity of Philadelphia, frost did not touch his land, which was rather higher than surrounding gardens, until the night of November 20, but that night the thermometer registered 12 degrees of frost, or 20 degrees above zero. He was a badly frightened man in the morning for the ice seemed to follow down the moisture filled stems clear to the tubers. He started digging at once and the tubers sparkled with a covering of frost when lifted up into the bright sunshine, while the stems were full of ice for several inches below the surface. Fortunately, he was among those who plant at least six inches deep, and did not lose a tuber.

As digging time approaches weather records should be consulted. The thoughtful gardener will make his own records, and have them for valuable comparison from year to year. Spring planting, and fall frosts vary at least thirty days, one year as compared with another, and it is just as unwise to wait too long in the fall before harvesting one's crops as it is to plant too early when fascinating seedtime is at hand.

As the fall days grow cooler, particularly the nights, and the period of sunshine is less, the dahlia plants begin to mature. It is time to dig the tubers up, even if frost has not come, when the production of blooms has practically ceased and the foliage shows that the plant is really no longer growing. It is far safer to dig than to wait for a frost that may be dangerously severe. 
Proceed exactly as after a frost. Cut the plants down with pruning shears, a keen corn cutter, or a sickle, as close to the ground as possible, because there are six inches of stem below the soil if the tuber was planted properly, and this is six inches of trouble in storing if you store bottom side up, which is the best plan.

Greatest care must be exercised in lifting the clump of tubers. One cannot be too careful. Growers with large plantations will congratulate themselves after the last load has been put into the storage cellar that this year, at any rate, very few necks were broken, only to find at cutting up time, when the clumps are divided, that the same sad tale remains, with a deplorable percentage of loss through "broken necks." A tuber with a broken neck is about as valuable as a man who has the same trouble. Both are dead ones, or will be soon.

The Irish or white potato and the sweet potato have "eyes" from which spring the sprouts. The dahlia tuber is without "eyes" as the dormant buds are popularly called. The underground buds of the dahlia are located upon the "crowns" of the tubers. These crowns are rather small enlargements of the "neck" of the tuber just where the neck or stem of the tuber is joined to the main stalk of the plant. When the clumps of tubers are divided in the spring (for only one tuber and one stalk should be allowed to grow at each position in the garden row), a portion of the central stem of the clump must be carefully left attached to the neck 


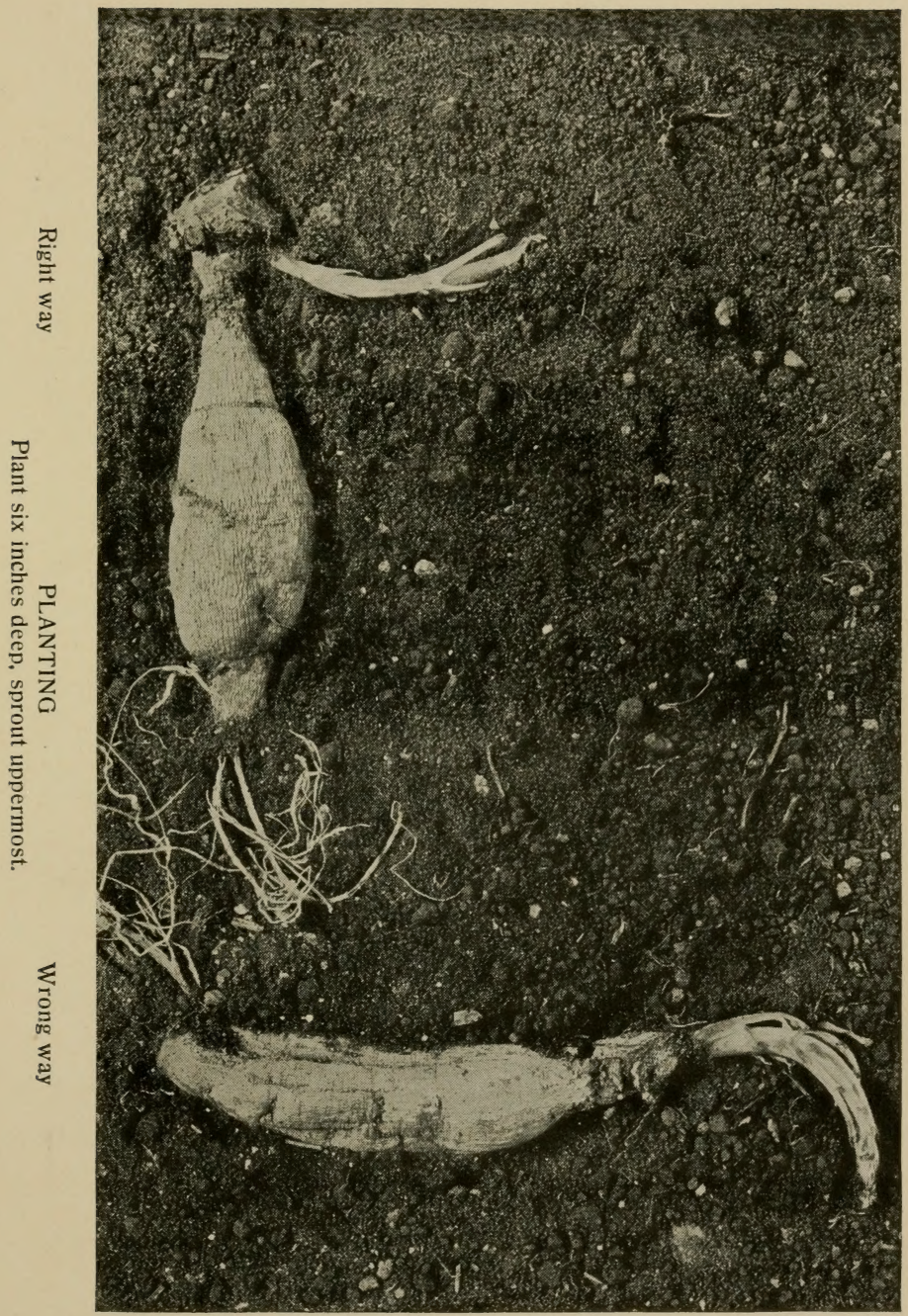




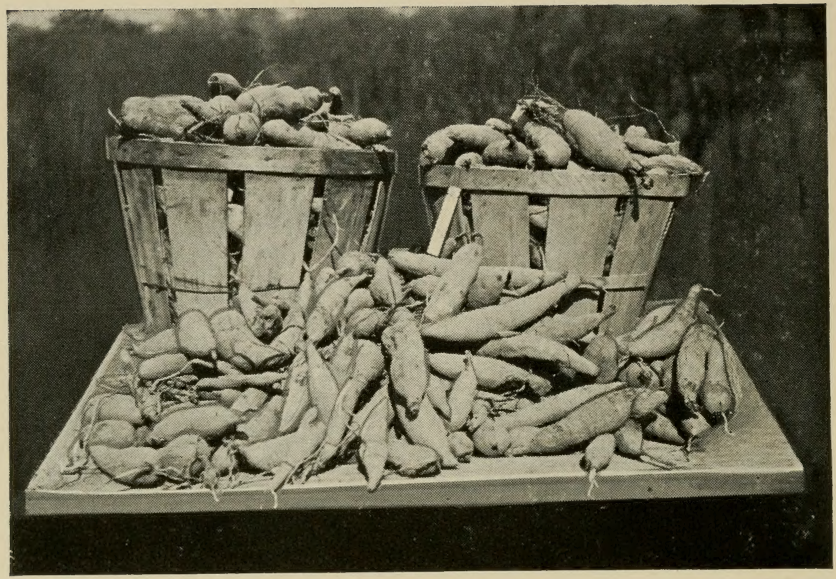

"Broken necks" of one amateur. Fine varieties, but absolutely worthless.

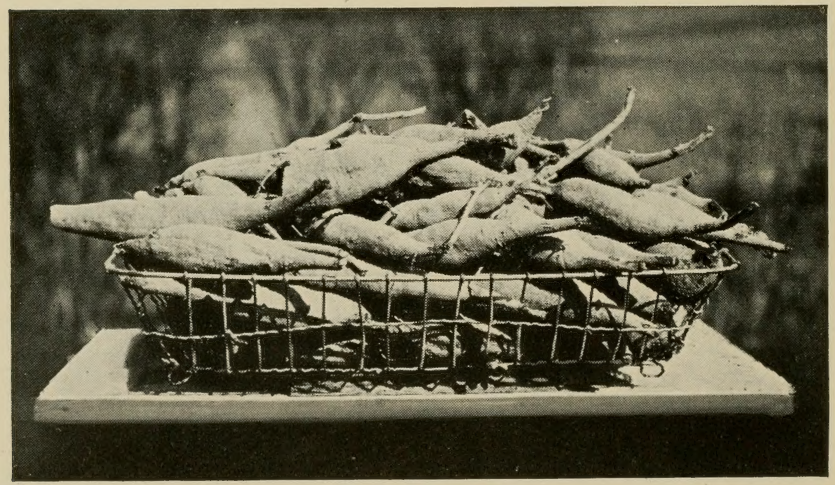

Necks broken. Catalog price $\$ 1$. anywhere-a very choice variety. All ruined by carelessness in digging and storing. 
end. Unless this is done a new plant will not be obtained. If the necks are broken, or even badly bruised when dug they will become mere dry threads of vegetable tissue by spring time, and this dryness will extend into the crown or bud enlargement where it joins the mainstalk, and the bud will be dead. The tuber itself will look perfectly sound, and will often be solid and plump. But the broken neck, often less than a quarter of an inch in diameter, and sometimes several inches long, which should have been an unbroken conduit for the transmission to the "eye" of the moisture stored in the plump tuber has been unable to perform its work. The main woody stalk of the clump has evaporated moisture all through the months of storage; the broken neck has been unable to supply any to the bud, and the bud is killed. Through carelessness in digging, resulting in many broken necks, tuber losses have been as high as eighty per cent. There is almost always some loss from broken necks. Some dahlia varieties have long slender necks and simply turning the clump bottom side up when digging will break the necks unless each heavy tuber is supported.

The home gardener, with a small dahlia collection, need not suffer this loss. With spade, or spading fork, or with shovel, he can dig around his clump, at a safe distance, removing earth enough to allow him to lift out the clump with his hands, with enough earth between the tubers, and more or less supporting them, to 
prevent absolutely neck breaking. It is not at all necessary to remove much of this soil before storing in the cellar. A slight shake or jar, or the pushing off of some of the earth with fingers or blunt end of a stake, is all that is needful. In fact, with heavy clay soils, the tubers dry out far less, and often come through the winter plump and hard and fine, if firmly imbedded in the ball of earth that is lifted with them. Of course such soil-filled clumps should not be piled up in the cellar when soggy with water, as is the case if dug immediately after rains. The roots should never be dug immediately after a rain. Wait twenty-four hours, or even two days. If weather predictions seem to make digging imperative while the ground is still wetter than ideal conditions demand, the earthy clumps can be exposed to sun and air for nearly a day, and not piled too high in the cellar, nor covered with old rugs or anything for nearly a week. So treated, a week's time will suffice for the stored roots to evaporate enough of their moisture to make final piling up and covering entirely safe. Tons of clumps thus treated have wintered so safely that in April the dried clay soil had to be pried off the roots in sections, and the hollowed lumps of clay were perfect matrixes of the surface of the tubers, while the tubers themselves, preserved from the evaporating action of dry, or possibly warm, cellar air, were "as hard as rocks" so firm and plump were they. Dug out of a soil almost entirely sand the clumps will free them- 
selves of the soil through the handling incident to digging and storing. In a rather loose loamy soil enough will drop off naturally.

The commercial grower sometimes has the help of a team of horses and a plow, along his rows, before lifting the clumps, but many go back to the eight or ten tined digging forks, "coke forks," such as are used on roads for lifting crushed stone. Two men, and they should have interest enough in their important work to be careful, take a row and dig the clumps, the two forks being pushed into the ground at a safe distance from the tubers as deeply as possible, nearly to meet under the clump, the men then prying out the mass of soil and roots with simultaneous action, the two workers uniting in lifting a clump.

The dug clump should be turned bottom up while exposed in the field for drying, and should be stored in the cellar bottom side up. This makes handling particularly laborious. The juice or sap in dahlia plants seems to have some acid content, and many growers believe that if the clumps are stored stem uppermost this sap will settle upon the crown (bud) ends of the tubers and injure them. J. K. Alexander, one of the longest experienced and largest growers in America states positively that he has found that many varieties decay if not stored upside down. He states that the watery stalk sap settles in the bottom of the stalks when the clumps are stored stem uppermost, keeps the crowns 
of the tubers wet, often causing the destruction of the entire clump through decay or other adverse action.

The clumps should not be laid directly upon concrete or earthen cellar floors, lest capillary attraction draw out the moisture and the tubers be shrivelled to death. Boards, barrel staves, excelsior, can be laid down and the clumps piled thereon. Straw matting, such as is used for floor coverings, or the matting around chests of tea, makes admirable separating material between layers of different varieties. Bamboo matting is practícally decay proof. A dozen or more clumps can be piled in a corner, a piece of matting laid on them, and another lot of clumps, of a different variety piled on top, or against the first lot, and so on, until four or five feet high. A ton of clumps can be stored in this manner, the bottom layer being in even better condition than the top one which is more exposed to the drying action of air, although covered first with matting, then with strips of old carpet, and finally with newspapers. Inspection two or three times during the winter is advisable. If stored without undue dampness when brought from the garden or field very little inspection will be found necessary. Lifting up a few clumps to ascertain if all goes well will be indicative of the entire pile. Care should be taken to exclude all frosted or green foliage, and all green stalks, as these will decay in the piled up clumps and may cause much damage by starting fungus and rot. 


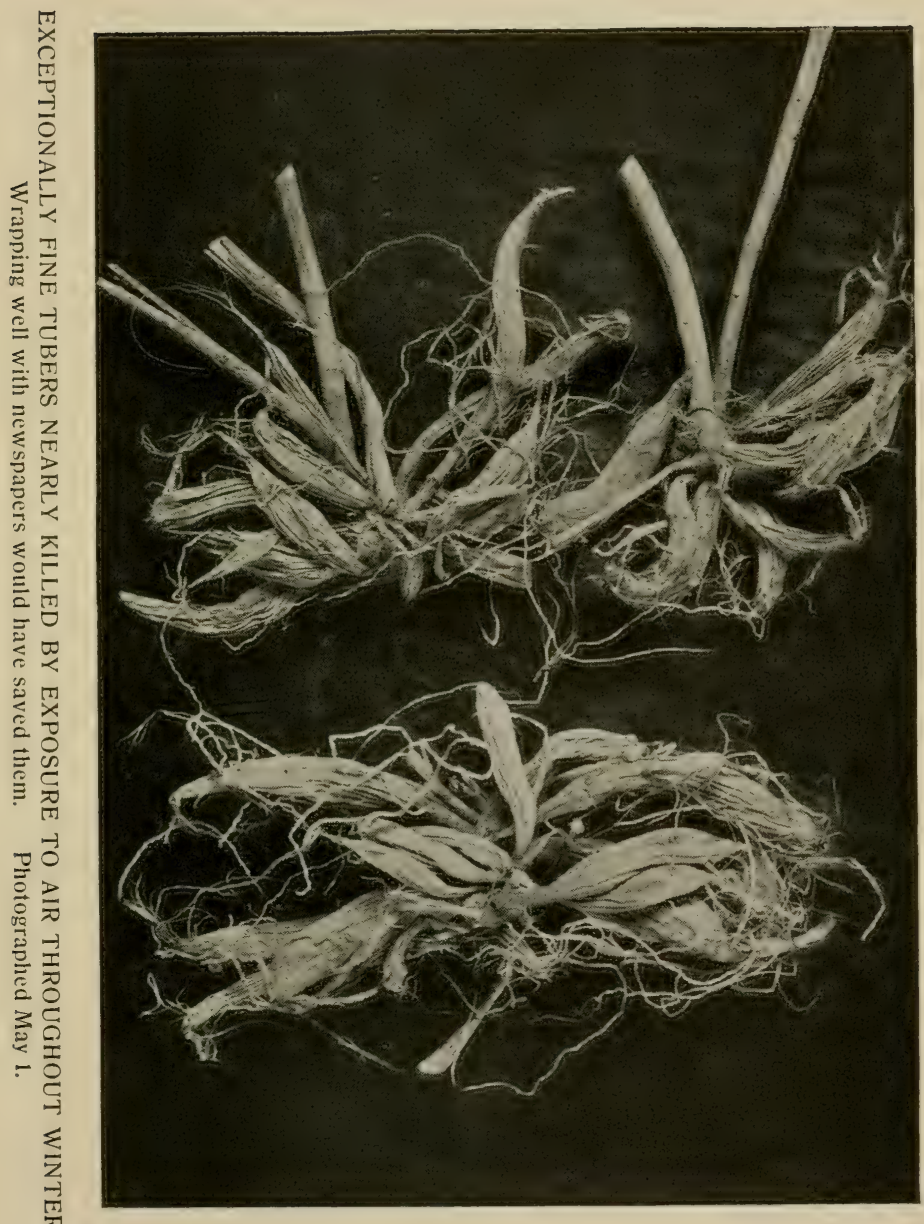




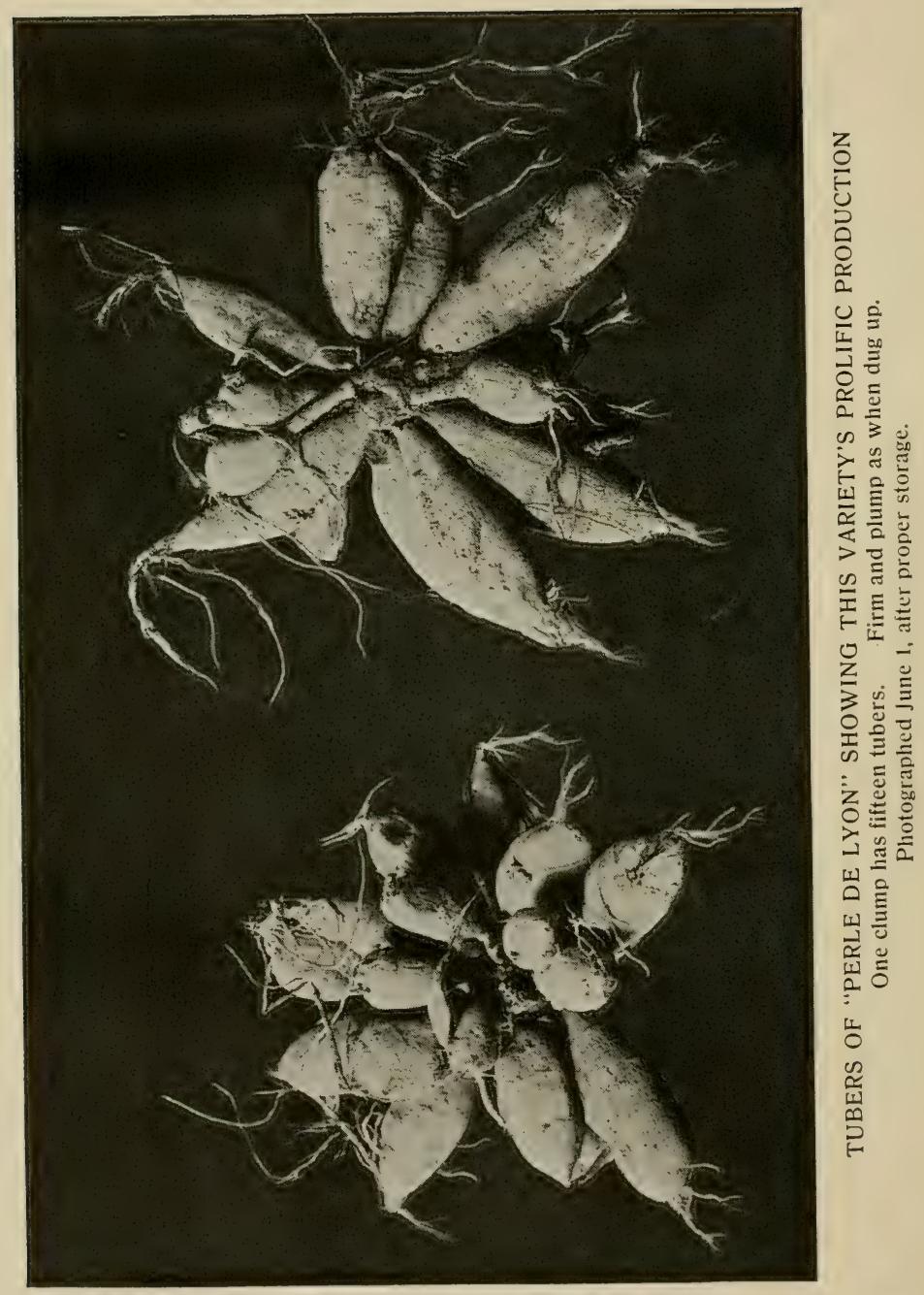


The home gardener with comparatively few clumps to store cannot do better than to use barrels and boxes. These should be lined with several thicknesses of newspaper or with a strong manila paper, to prevent too much air circulation, and after the clumps have been in the containers a few days in the cellar (less than a week) they may be covered with paper, and then boards or pieces of carpet. These small lots should be inspected every month; and covered more closely if shrivelling seems to be taking place.

Home cellars are not always ideal storage rooms. It may be difficult to keep frost out in severest weather, or perhaps they may be too warm all the time. Fortyfive degrees is just right for dahlia roots in storage, and an accurate thermometer is an excellent investment, keeping it alongside the roots, where average heat or cold prevails, and looked at, when storage is in the home cellar, every morning when the furnace is visited. Undue cold can thus be guarded against, and an undesirable amount of warmth, if any noted. The clumps can sometimes be moved to a better location after thermometer readings have been taken for a time. If in spite of everything the tubers shrivel up too much they may be sprinkled cautiously with water now and then, but must be carefully observed from week to week lest warmth and moisture start the sprouts. A friendly neighbor, with an ideally cool cellar (fortyfive degrees), may be glad to accommodate your roots 
along with his own, and the exchanging of a variety or two in the spring will make this convenient and safe storage an annual one for the home gardener who has too warm a cellar.

Where cellars are not frost-proof in mid-winter, dahlia clumps have been wrapped in a number of newspapers, tied tightly as individual packages, and stored in an attic or in the closet of an unheated room, and wintered safely. Temperatures should be observed, of course, lest these storage places reach thirty-two degrees or less, in severest cold weather. A lighted lantern, placed on the floor of a very cold cellar, with two or three buckets of water near by, will keep frost away during exceptionally cold snaps, and safely carry the stored roots over the usually short period of very low temperature.

If an abnormally cold cellar is entirely dry throughout the winter, twelve to eighteen inches of perfectly dry straw closely packed around the roots would probably carry them through safely. This is a practice of some English growers, using thick packings of dry straw in cellars, sheds, or cold rooms. It would not be safe to rely altogether upon it in the colder portions of the United States. Yet in well built barns, where watering troughs for cattle seldom freeze, and never more than skim over with ice in the coldest weather, thick protection with perfectly dry straw or hay would take dahlia roots through the winter in safety. Protection from 
rats and mice does not appear to be necessary. The roots are apparently not palatable to these pests, and many growers have suffered no loss through a period of a dozen years, though evidence of the presence of rats was plain enough.

Inspection from time to time in the winter is strongly recommended. Decay from any cause, fungus, dampness, injuries at digging time, rotting foliage accidently included in the storage, will not only destroy the roots directly involved, but may spread to surrounding clumps and losses equaling a quarter and even a third of the entire crop have been reported. If, when inspected, decay spots, or rotted tubers, are found, cut away all the spoiled portions, sprinkle powdered lime over the cut surfaces and carefully pile up again.

Some of the most beautiful and desirable modern dahlias, the new creations, are extremely difficult to carry over the winter. Storm King, a superb white dahlia, is one such. Some amateurs store these sensitive varieties that so easily shrivel up and die during the winter in trunks or tightly covered boxes. Considerable earth is left clinging to the tubers. Often roots so stored go through the winter safely. But they should not be so stored in metal containers. The inevitable partial evaporation will condense on the inside metal walls, and mould and decay of roots is sure to follow. One amateur filled several large galvanized ash barrels with roots placing wooden covers rather tightly upon 
the tops. In one month's time the insides of the steel barrels were literally dripping with moisture. Prompt emptying of the roots saved them from rotting. Wooden barrels and boxes do not have this objectionable feature, the wood allowing the slowly evaporated water from the tubers to pass through its fibers to the air.

Amateurs are sometimes advised by the ignorant to cover their roots in storage with sand, or sawdust, shavings, dried earth, ashes, ground cork. Do not use any of these materials. Paper lined barrels or boxes, with a top covering of paper, and wood or rugs, not too tightly laid, will answer for almost all ordinary varieties. For the latest and most sensitive sorts, as previously stated, something else is necessary, and some amateurs devoted to the most expensive varieties, claim that something like sand or dried earth must be used. But any of the materials mentioned hold moisture, and roots packed in them are pretty sure to mildew or rot. Do not cover your ordinary roots with anything save wood, paper, matting, or carpets. The clumps stacked upon each other seem to be according to nature's liking and only need the surrounding protection of paper, wood, etc. The specialist with exhibition dahlias only, and these are the most sensitive sorts, dips any bruised or cut surfaces of the tubers in powdered sulphur. This is an excellent practice with any variety. He will not store in sand under any circumstances, as sprouts will start if the sand is damp; while if the sand be practically 


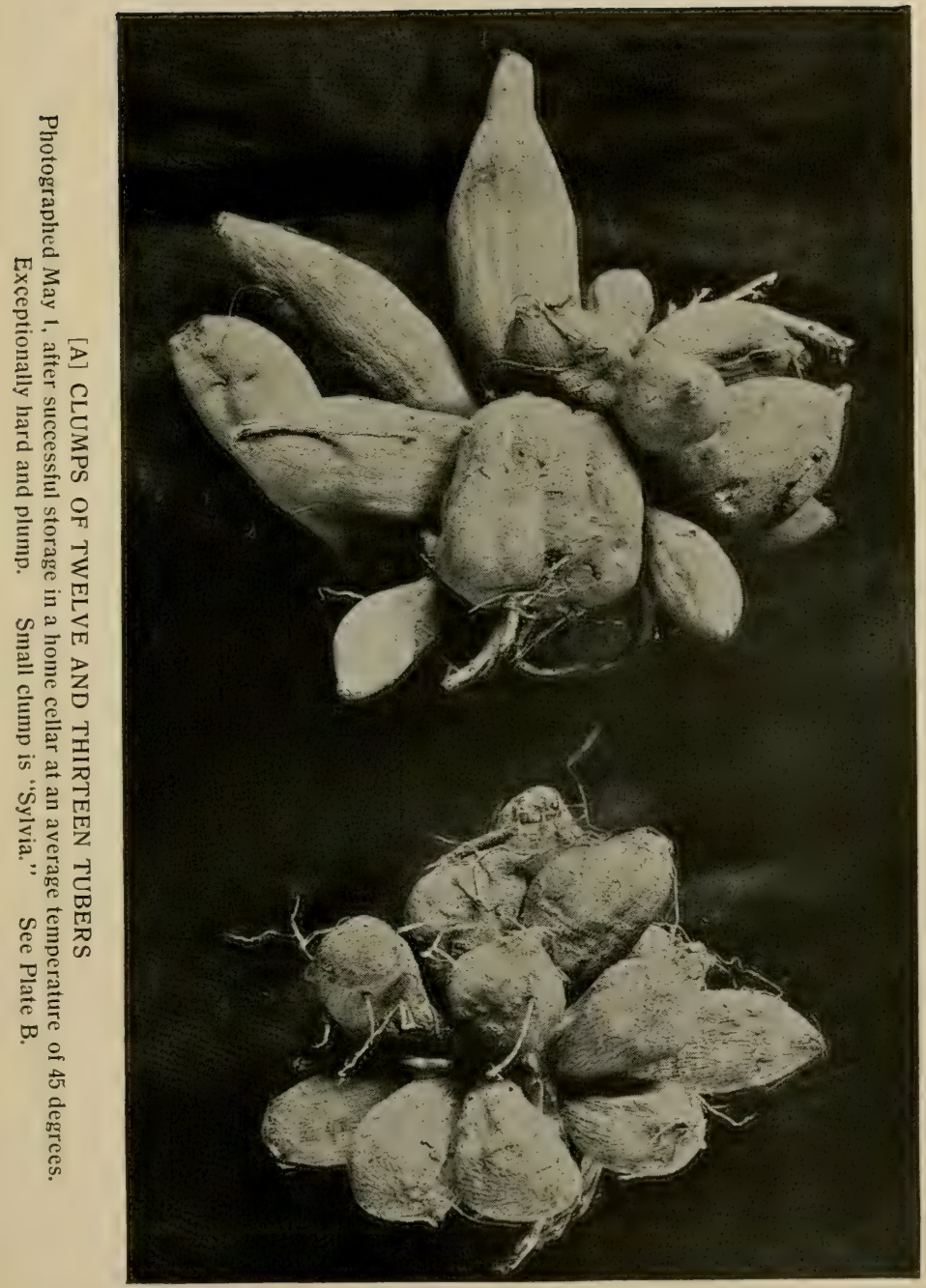




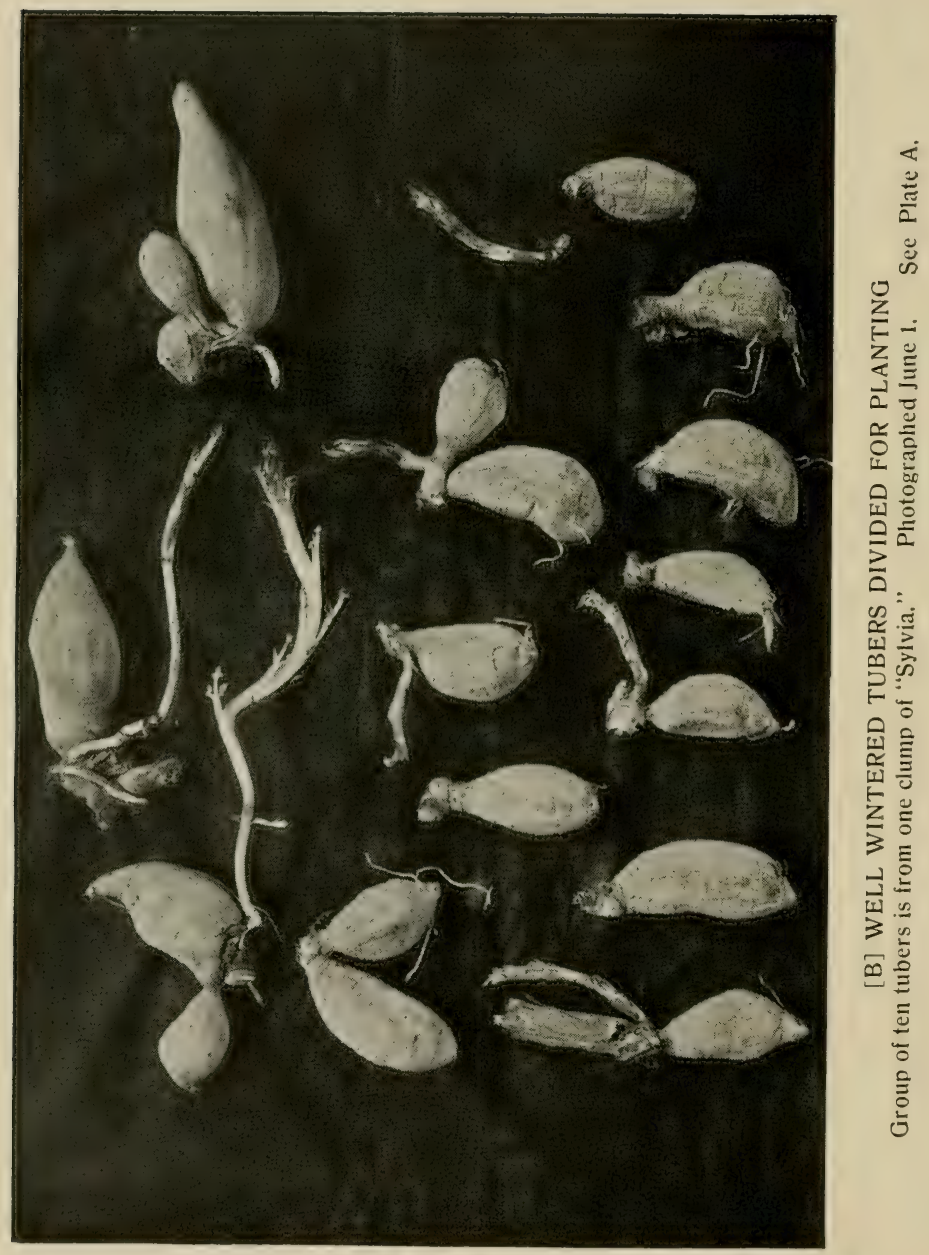


kiln dried it will absorb vital moisture from the tubers and render them worthless.

A temperature range of 40 to 50 degrees is safe and satisfactory. But it should be remembered that at 32 degrees frost ensues, and the tubers will be killed.

In the South, where unnecessary work is not particularly courted, dahlia roots are left in the ground all winter by many gardeners. A forkful or two of leaves or litter may be placed over the ends of the stalks by the more ambitious. In the spring the clumps are dug up and the surplus, after planting, put in the shade of a tree where neighbors come and get them after the hospitable way of Dixie land.

California growers have their troubles, but not from frost. The dry atmosphere of the southern half of the state is the main difficulty. Irrigation must be practiced during the long cloudless months, and during the resting period of the plants protection from the dry air, which is likely to cause the roots to dry so completely as to entirely destroy, must be as perfect as possible. December will find some plants still blooming well. The safest plan seems to be that of leaving the roots in the ground; this is true for most of California, and for the Pacific coast generally west of the Cascade and Sierra Nevada mountains, as far north as Seattle. The roots are undisturbed until planting time comes again, unless grown in a heavy clay soil, or in such low land that water remains in pools after rains. Standing water on 
and in the soil is a certain cause of decay of tubers. When the plants mature the growers cut off the tops close to the ground, and hill up the stumps. This provides a water shed over the roots, and protects from moderate frost if such comes along. The clumps are not dug until it is time to divide and plant. The necessity of a storage cellar and all the labor it involves is done away with.

Inexperienced amateurs, who start their first year ambitiously with a fine lot of plants, often wonder how many they will have of their own raising to plant the following spring. One dahlia plant will average thirteen tubers as its summer production, besides scores of blossoms. Probably the clump can be divided into six or even eight plantable tubers. The amateur who starts his first year of dahlia delights with fifty tubers will have at least five bushels of clumps in the autumn, and not less than 300 tubers to plant the next spring, if his roots go safely through the winter. An acre of dahlias, about 5000 plants, produces more than four tons of roots, which can be stored in a bin twelve feet square, and four feet deep. The clumps when divided into as nearly single tubers as possible for planting do not take up half as much room, stowing more closely, besides the elimination of stems and clinging earth. Cutting up, or division, should not be done until nearly planting time, of course, as each cut surface makes shriveling up more likely. 
After a frost fifteen days of fine weather has often been known to follow. The temptation to postpone digging, even if the tops are dead, presents itself, but should be resisted. Continuous mild and somewhat wet weather will cause the tubers to sprout, and these sprouts it is most desirable to hold dormant until the following spring. The premature sprouting also weakens the tuber.

These after-frost sprouts that come up if digging is delayed and warm weather prevails, are most undesirable for another reason. They are of soft, very green, succulent growth, without woody substance of any kind. When the roots are finally dug these sprouts are cut or broken off close to the ground, of course, but the soft growth below the soil is lifted with the clump and stored. This sprout is full of water, is spongy tissue, not hardened, and will decay during the winter. It may, and sometimes does, destroy the entire clump by communicating its decay. Clumps dug within a week after frost will be free of this particular danger.

The home gardener always spears potatoes on the tines of his digging fork, and will be as cruel to his dahlias if he doesn't look out. Tubers broken in two, or perforated by a fork tine, will go through winter storage unharmed in most instances. Such injuries should be carefully avoided, however, particularly in heavy soils that carry the fungus of black rot. The cuts, bruises and fractures occuring in digging afford so many open- 
ings in the tough protecting shell of the tuber through which the fungus can pass and produce deadly decay. Dahlia tubers are very susceptible to fungus attack, and fungus means decay, and tuber loss. This danger is another reason for placing boards or other suitable insulation between roots and either a concrete or an earthen cellar bottom. A reason, also, for not sprinkling tubers with water during the winter unless absolutely imperative. Mould, decay, premature sprouting, must all be guarded against and can be usually prevented. Exceptionally valuable roots should be individually inspected once a month throughout the winter.

The amateur has the exceedingly helpful advantage of not needing to cut up his clumps until late spring. The commercial grower who has large crops must start dividing soon after January begins. Some growers find storage of the cut up (divided) tubers in closed wooden boxes prevents any damage by drying out. Exclusion of air, an even and low temperature, should be secured. Some consider packing in cocoanut fibre refuse an excellent method, others regard finely divided sawdust, sifted and dry leaf mould, or screened peat, or sand, desirable.

Commercial growers often build a specially designed storage building, or cellar, of concrete, which ensures evenness of temperature. Wooden bins with movable partitions facilitate separation of the varie- 


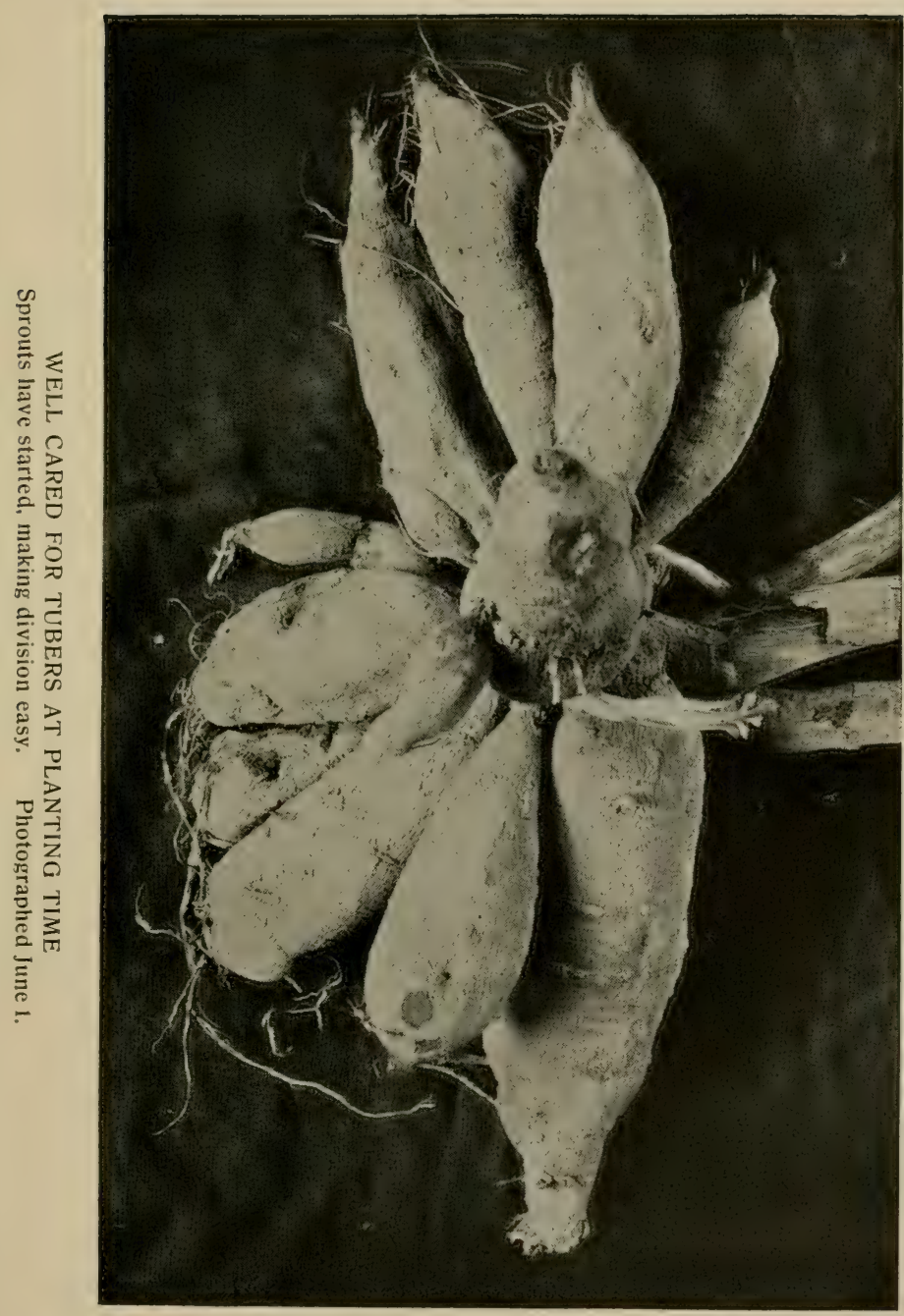




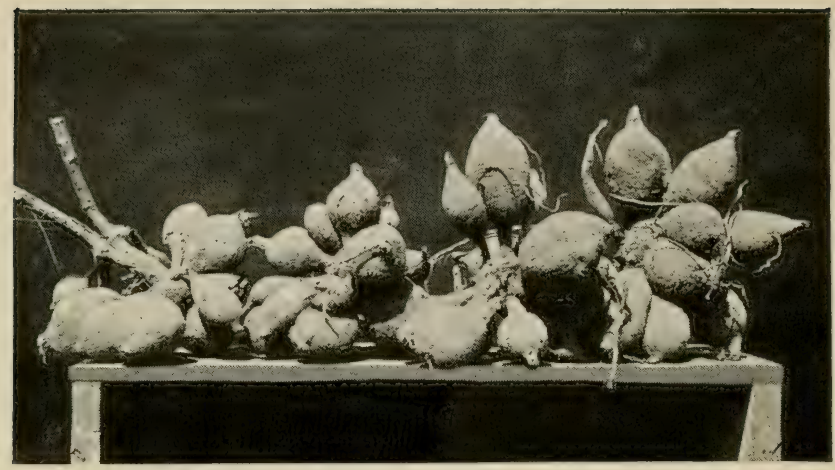

"Jack Rose." Photographed June 1, after protection by being covered with newspapers and old carpet since day they were dug.

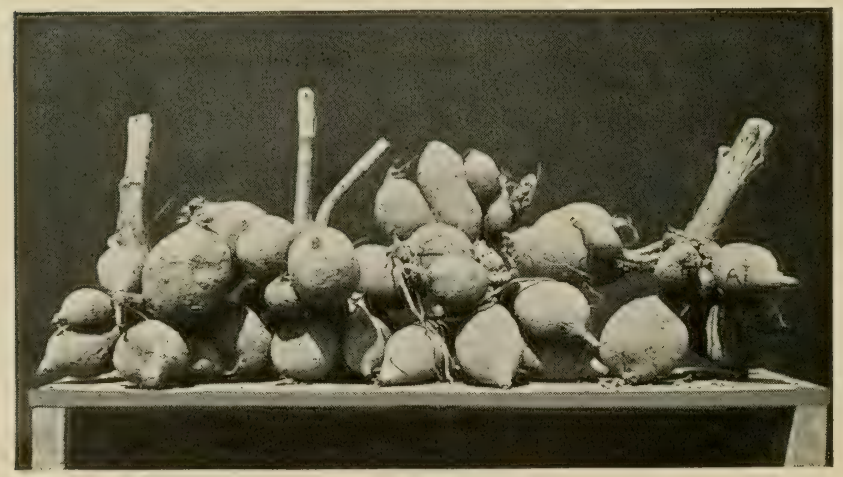

Fine plump tubers, ready to be planted. Wintered at average temperature of fifty degrees, in home cellar, ten feet from hot water heater.

Protected from air by newspapers and burlap bags. Photographed June 1, day taken from pile. 
ties. Slots formed by cleats nailed on the sides allow separation boards to be quickly placed between the sorts as storage proceeds. This is a good plan for the amateur. In fact preparedness of every sort for harvest time is most helpful. Then the work of removing the crop from the ground to storage can proceed without confusion, and with that quietness of spirit which makes for joyousness in gardening. If there is a window over the storage bin it will be well to equip it with cord and pulleys for opening or closing. When the bin is filled with roots the window may be hard to reach.

Preparedness with suitable tags cannot be too much emphasized. There is no reason why you should not know your dahlias by name, and it is embarrassing to a genuine garden lover not to be able to answer the queries of visitors who come to admire his blooms. The tags growers send out with the tubers are not very suitable for exposure to weather and the close packing of storage. Half a season usually makes them unreadable. Neither is the attaching wire durable enough. If iron it crumbles with rust before the summer is over. The self-respecting and careful gardener will have legible tags, strongly wired, attached to plants, or stakes, before harvest time. As the end of the growing season approaches he will go through his garden and be sure that each tag is accurately identified with the plant it represents. Slender wire will be replaced by strong 
copper or galvanized wire. In many cities, and at amusement parks, slot machines may be found that for a cent or two will punch names in raised letters on strips of aluminum. Such tags are ever-lasting, can always be read, the soil that may become attached to them in storage piles can be rubbed off in a moment without injuring their legibility in the least, and they cannot rust or decay. Amateurs can make their own tags from strips of wood. Odds and ends picked up at building operations, or at the carpenter shop, for a few cents, can be sawed into blocks of size and shape to suit individual taste. Pieces five inches long, an inch and a quarter wide, and at least half an inch thick make excellent tags. Any wood that will not warp and split readily under the effect of rains and sunshine is suitable. Two coats of white paint is very desirable, making the name more legible. A very black pencil, or a shipping crayon may be used to write or print the name on the tag. Black paint is best of all. Wire can be attached through a hole half an inch from one end of the tag. Such a tag is readily noted amidst the foliage of the growing plant, and cannot be lost in the debris of the storage pile. Unless it has been strongly and pretty tightly wired to the stalk close to the ground just before digging, it should be wired around a cuber's neck in the clump immediately upon lifting from the ground. The wire should be loose enough not to cut the neck, yet close enough to prevent slipping off over the tuber. 
Placing around the neck is an insurance against the mixing of tags, since it cannot slip off no matter how much the tuber may shrink in size during the winter from undue dryness. When tags are wired to the main stalk of a clump they often become detached, since the stem will greatly reduce its diameter by drying, and the loosened wire loop slips off as the clumps are handled in the spring. In the great days of tulip growing in Holland generations ago, when portly and wealthy burghers spent fabulous sums upon single bulbs, a famous grower was able to identify one thousand different tulips by name by carefully looking at the bulb, and remembering the little and obscure differences in form and other appearances. No dahlia enthusiast has yet arisen with equal ability in his chosen realm, and the average man cannot be too careful about tagging. 




